Clair, Saskatchewan, is a long way from the turkey's natural range. I am curious to know whether other sightings of these birds have been made in this area. Speculation leads me to wonder if these Wild Turkeys were released or had escaped from a neighbouring farm.

1 BELCHER, MARGARET. 1982. 40th annual Saskatchewan Christmas Bird Count-1981. Blue Jay 40:17-29.

${ }^{2}$ GODFREY, W.E. 1966. The birds of Canada. Nat. Mus. of Canada Bull. No. 203, Biol. Ser. No. 73. $428 \mathrm{pp}$.

${ }^{3}$ HOUSTON, M.I. 1981. 39th annual Saskatchewan Christmas Bird Count-1980. Blue Jay 39:13-24.
4 1983. 41st annual Saskatchewan Christmas Bird Count-1982. B/ue Jay $41: 12-25$. 1984. 42nd annual Sasskatchewan Christmas Bird Count-1983. Blue Jay 42:26-39.

6 1987. 45th annual Saskatchewan Christmas Bird Count-1986. Blue Jay 45:4-19.

7 1988. 46th annual Saskatchewan Christmas Bird Count-1987. Blue Jay 46:9-28.

BOBBINS, C.S., B. Bruun and H. S. Zim. 1966. A guide to field identification. Birds of North America. Golden Press. New York, N.Y. 340 pp.

\title{
MELANISM AND HAIRLESSNESS IN THE RICHARDSON'S GROUND SQUIRREL
}

HUGH C. SMITH, Provincial Museum of Alberta, 12845-102 Avenue, Edmonton, Alberta. T5N $0 \mathrm{M} 6$

Aberrant pelages in the rodent family Scuiridae are not unusual. In some species, such as Woodchuck, melanism and albinism occur on a regular basis. In other species such as the Gray Squirrel, the melanistic morph occurs in some populations to the exclusion of the normal morph. Other species exhibit little or no pelage aberrations. The Richardson's Ground Squirrel is one such species. I have been able to find one reference to albinism ${ }^{1}$ and none to melanism in this species. Recently, the Provincial Museum of Alberta received two specimens of Richardson's Ground Squirrel that are worth reporting because of their aberrant pelage.
The first specimen, a melanistic form (PMA No. 88.16.1), was obtained in the Didsbury area of central Alberta in June 1988. The individual is well furred with hair of normal length but entirely black in colour. The specimen was collected in a roadside ditch beside a field that was used to pasture livestock. A number of other black ground squirrels ( 25 to 30 ) along with a large number of normal-coloured individuals was observed in this pasture. An interview with a person who lived nearby revealed that the landowner allowed the shooting of "gophers" on this land, but only if they were of normal colour. The black individuals were not to be shot. The following standard 
museum measurements were obtained from the specimen label: adult, male, weight $417.7 \mathrm{~g}$, total length $330 \mathrm{~mm}$, tail $83 \mathrm{~mm}$, hindfoot $50 \mathrm{~mm}$, ear from notch $13 \mathrm{~mm}$.

The second specimen (PMA No. 85.18.1) was collected near Spruce Grove Alberta, in July 1985 . The specimen has a black skin and is almost entirely hairless. There is a scant covering of extremely short hair on the head and the posterior portion of the back. Vibrissae [whiskers] are present but they are very short and few in number. The central back, sides, belly, and front and hind legs lack any hair covering. There is dark gray hair on the front and hind feet but it is very short and thin. The skin is dark brown or black on the back and creamcoloured on the chest and underside of the legs. The belly is darker than the chest. The tail is round, tapered and hairless. The museum specimen label reads: sub-adult, female, weight $224.4 \mathrm{~g}$, total length $277 \mathrm{~mm}$, tail length $70 \mathrm{~mm}$, hind foot $45 \mathrm{~mm}$, ear from notch $11 \mathrm{~mm}$.

DuBowy and DuBowy reported an instance of hairlessness in a Goldenmantled Ground Squirrel and stated that they were not aware of hairlessness in other ground squirrels. ${ }^{2}$ They believed the squirrel they saw was fully grown but could not determine whether it had overwintered. They observed the ground squirrel in August. Hairlessness has also been reported in the House Mouse. ${ }^{3}$ In this case two individuals were reported from separate locations. As well as being hairless, the mice exhibited an excessive growth and folding of skin. The specimens were called "rhinoceros mice" because of the skin condition. The ground squirrels reported by DuBowy and DuBowy and the Spruce Grove specimen do not show any excessive skin growth. ${ }^{2}$

Specimens housed in the Provincial Museum of Alberta yielded the following data for 20 adult female Richardson's Ground Squirrels: weight (g): mean 332.5 , range $273.2-375.0$; total length $(\mathrm{mm})$ : mean 292.8, range 284-306. Comparing the weight and total length of the
Spruce Grove specimen to these mean measurements shows that the Spruce Grove specimen has achieved $67 \%$ of the mean adult weight and $95 \%$ of the total length of Alberta female Richardson's Ground Squirrels. This would suggest that the Spruce Grove specimen is a young of the year and has not overwintered. The chances of such an individual successfully overwintering seem rather slim, as even "normal" young of the year have a high overwinter mortality. ${ }^{4}$ It would appear then that this animal would not be in the breeding population and that the genetic basis of hairlessness, if in fact the condition is the result of a mutation, would not become established in the population.

The situation with the melanistic form is entirely different. Once the landowner observed black individuals on his property he enhanced their chances of survival by not actively killing them, while he had no concern about eliminating the normal-coloured morphs. No one to whom we spoke was able to tell us how long the melanistic forms had been around. We surmised, from the number of individuals counted and the fact that the individual collected was an adult, that it must have been for some considerable time. If this is so, and if an active program is in place to enhance the survival of black individuals, the genetic pool for the black morph will be greatly enhanced and more melanistic individuals can be expected to occur in the area.

${ }^{1}$ DEW, J. 1971. Albino gophers. Blue Jay 29:142.

${ }^{2}$ DUBOWY, P.J. and V.S DUBOWY. 1988. Hairlessness in a Golden-mantled Ground Squirrel. Prairie Nat. 20:231-232.

${ }^{3}$ GOEHRING, H.H. 1971. Two Rhino Mice (Mus musculus) from Minnesota. J. Mammalogy 52:834-835.

${ }^{4}$ SHEPPARD, D.H. and S.M SWANSON. 1976. Natural mortality in Richardson's Ground Squirrel. Can. Field-Nat, 90:170-172. 